\title{
SUPERVISION OF HALAL FOOD AS IMPLEMENTATION OF SHARIA- BASED HOTELS IN JEMBER CITY (CASE STUDY OF THE SEVEN DREAM SYARIAH HOTEL)
}

\author{
Syah Riza Octavy Sandy \\ Universitas Muhammadiyah Jember \\ syahriza@unmuhjember.ac.id
}

\begin{abstract}
Food is a basic need for every human being. As a basic need, food must always be available at all times, safe, quality, nutritious and expensive prices by the community. Food needs can be directly taken from nature and food obtained through a process called processed products. Both of the foodstuffs obtained must be safe and not harmful to the soul. This food can be called a healthy food in the sense that it is a hygienic food product and is also free of biological contaminants, chemicals and other objects that can be lifethreatening.The Islamic view of suitable food is halal in the sense of halal, then the process, process and achievement. Halal food is defined as food that does not contain anything that is haram with an understanding of how to obtain it, how to process it and process it in accordance with Islamic law.This study aims to analyze restaurant supervision as a hotel implementation based on sharia based on accurate data and information in this case represented by the Seven Dream Hotel, which is the only Shari'ah hotel in Jember.This type of research uses the type of qualitative research. Data collection using interview techniques, library research and documentation studies. The next stage is the preparation of the final report based on the results of data analysis within the framework of making scientific articles and scientific publications. The results of taking the two outputs or outcomes are then sent to the parties taken.
\end{abstract}

Keywords: Supervision of Halal Food, Syari'ah Hotel Restaurant 


\section{INTRODUCTION}

Food is a basic need for every human being. as a basic need, food must always be available at all times, safe, quality, nutritious and especially affordable prices by the community. The need for food can be directly taken from nature and food obtained through a process called processed food products, both of the foodstuffs obtained must be safe and not harmful to the soul. Food can be referred to as healthy food in the sense of being a hygienic food product or free from biological, chemical and other contaminants that can be life-threatening.. Biological, chemical and other harmful substances are things that must be examined, biological contamination of food products contaminated with harmful microorganisms (pathogens), chemical contamination of food products is food that has been contaminated by chemicals such as pesticides and toxic materials. Food products are said to be healthy if they contain nutrients needed by the body to be healthy, nutrients include carbohydrates, proteins, vitamins and minerals. The amount of nutrition needed must be in accordance with the body's needs so as not to cause malnutrition.

The Islamic view in particular about suitable food is halal in the sense of halal in substance then in processing, processing and obtaining it. Halal food is defined as food that does not contain anything that is haram with an understanding of how to obtain it, how to process it and process it in accordance with Islamic law.Countries with the largest Muslim majority are Indonesia, in this case the government is responsible for providing productsappropriate and halal food, in this case halal food products are already obligatory, there are also in the holy quran as a guide for Muslims about halal food products.Some evidence that Muslims are obliged to consume halal and good food in the holy book Al-Qur'an Al Maidah verse 88: And eat halal food that is better than what Allah has sustained you, and fear Allah whom you have faith in Him. Surah Al-Baqarah verse 173.Verily Allah only forbids you carcasses, blood, pork, and animals that (when slaughtered) are called (names) besides Allah. But whoever is in a state of compulsion (eat it) while he does not want it and does not exceed the limits, there is no sin for him. Truly Allah is Forgiving, Most Merciful.Surat Al An'am Paragraph 121And do not eat animals that are not called the name of Allah when slaughtering them. Indeed such actions are a.wickedness. Verily the devil whispers to his friends that they will refute you; and if you obey them, surely you will be polytheists.The study of halal and haram foods in the Holy Koran contains approximately 18 verses.A hotel is a type of accommodation that uses part or all of an existing building by providing lodging, food and beverage and other supporting services, functions as a temporary place and is made available to the public, managed commercially by taking into account the profit and loss, and aims to obtain benefits in the form of money as a benchmark.

The term Sharia to indicate the use of the Islamic system in carrying out economic activities, seems to be starting to spread widely in various business sectors. Starting in the Sharia Banking Industry, which began in 1992, then followed by other sectors, such as Sharia Insurance, Sharia Pawn Shops, and since 2013, there has now begun to appear trends in Sharia Hotels and Sharia Tourism. The development of sharia hotels is starting to 
follow the demands of today's society. Developing a Sharia-based hotel is not like developing a conventional hotel. Basically there are several requirements that must be met, such as the principle of Sharia itself which is inseparable from Islamic principles. The development of Sharia-based hotels has increased from year to year. This is due to the development of people's mindset about Sharia principles, with one of the strengths being to provide a sense of security and comfort. The scope of the Sharia hotel business is not limited to the Muslim community, but is intended for other general public. In terms of management not much different from the hotel operating system in general. The restaurant is a section of the food and beverage department. According to Agusnawar it is stated that the restaurant is "part of a hotel whose scope of activities is to provide food and drink for guests staying overnight in the hotel and for the general public".According to Suarthana and friends (2006) Restaurant is "a commercial place of business whose scope of activities is providing dishes and drinks at its place of business".From various information that has been obtained, restaurants in Sharia-based hotels are still a question among ordinary people is there any guidelines for halal supervision. From this, the researchers are interested in making restaurants in Sharia-based hotels a topic of discussion in this study.

\section{Problem Formulation}

The problems in this study lead to the supervision of the halalism of the Islamicbased hotel Restorandi with the following problem formulation:

1. Supervision of halal restaurant as the implementation of Islamic hotels (Seven Dream Syariah hotel case study)?

2. How is the supervision of halal restaurant as a sharia hotel implementation?

\section{Specific Research Objectives and Research Urgency}

The purpose of this study is to find out:

a. Want to review the halal surveillance system Restaurant as the implementation of Islamic hotels.

b. Want to know how the Supervision of the halal restaurant as an implementation of sharia hotels (Seven Dream Syariah hotel case study)?

The urgency (virtue) of this research is that this study will obtain management designs, procedures, policies and services in Sharia-based RestoranHotels.

\section{REVIEW OF LITERATURE}

Understanding of hotels according to the Minister of Finance Decree. Travel, Post and Telecommunications No. KM / 37 / PW-340 / MPPT-86 are as follows:

"Hotels are a type of accommodation that uses part or all of a building to provide accommodation, food and beverage services and other services to the public, which are managed commercially."

Based on this understanding it can be concluded that the hotel must:

a. A type of accommodation.

b. Use part or all of the existing building. 
c. Providing lodging, eating, drinking and other services.

d. Provided to the public.

e. Commercially managed. Whereas the understanding of Inn is:

"A commercial business that uses all or part of a building specifically provided for each person to obtain lodging services."

From this understanding it can be concluded that inns must:

a. Commercially managed.

b. Use part or all of the parts.

c. Provided for everyone.

d. Providing accommodation services.

e. Does not provide food, drink and other services.

To get to know the types of hotels can be seen from the various criteria used to classify them. The types of hotels according to the criteria are as follows:

a. According to the element or component of the room price (plan)

1). European Plan: Room rates consist only of room rentals. While the food is calculated separately according to guest tastes.

2). American Plan: Room rates are included with the price of food served to guests, regardless of whether the guest will eat or not.

There are two types of American Plans:

- Full American Plan (FAP), which is the price of a room including three meals a day (breakfast, lunch, and dinner).

- Modified American Plan (MAP), which is the room price includes two meals where one of them must have breakfast (breakfast), such as:

- room + breakfast + lunch.

- room + breakfast + dinner.

3). Continental Plan: Room rates where the price includes a continental breakfast

4). Bermuda Plan: Room rates where the price includes American breakfast.

b. According to the size or number of rooms Based on the number of rooms owned by a hotel, it can be grouped into sizes:

1) Small Hotels: Hotels that have a number of rooms up to 25 rooms.

2) Medium Hotels: Hotels that have a number of rooms between 26 and 100 rooms.

3) Medium Hotels: Hotels that have a number of rooms between 10 to 300 rooms.

4) Large Hotels: Hotels that have a number of rooms above 300 rooms.

c. By Type or Guest Type

1) Family Hotels: Hotels where guests are more devoted to those who are visiting with family.

2) Tourist Hotels: Hotels where the guests mostly consist of tourists

3) Transit Hotels: Hotels where the guests who stay mainly are those who will continue their journey.

4) Cure Hotel: The hotel where the guests who stay are mostly those who will take care of themselves for the purpose of treatment. (mineral hot water and others.)

d. According to the intended use during the stay. 
Based on the destination factors during the stay, it is divided into two parts, namely:

1) Business Hotel.

A hotel that is widely used by business people. This hotel has complete facilities for businessmen.

2) Recreational Hotel.

Hotels that are widely used by people who will relax or relax.

e. According to the location factor.

Based on the location factor, it is divided into five parts, namely:

1) City Hotel is a hotel located in the city, where most of the guests staying are doing business activities.

2) Resort Hotel

3) Resort hotel is a hotel located in a tourist area and most of the guests who stay do not do business. Types of hotel resorts by location include:
a) Mountain Hotel
b) Beach Hotel
c) Lake Hotel
d) Hill Hotel
e) Forest Hotel

4) Suburb Hotel.

Suburb Hotel is a Hotel Hotel that is located on the outskirts of the city, which is a satellite city, which is a meeting city between two municipalities.

5) Urban Hotel.

Urban hotel is a hotel located in the countryside and far from big cities.

6) Airport Hotels.

Airport Hotel is a hotel located in the airport area and most of its guests are from airplane passengers who were delayed on flights and flight crew.

\section{RESEARCH METHOD}

The research method used in this study is a descriptive method with a quantitative approach. The research variables are as follows:

\section{Research Variables}

The research variables observed in this study are:

a. Objection Control

b. Implementation of Sharia-based hotels

\section{Types and Sources of Data}

\section{Data type:}

a. Qualitative data is data that is not in the form of numbers, including characteristic conditions, such as age, gender, education, origin, occupation of the respondents which are subject to research. This qualitative data is needed to find out the respondent's background, both regarding social, economic, educational conditions and so on.

b. Quantitative data is data in the form of numbers covering the number of hotel industry in Jember, number of room occupancy, number of employees, operating costs, 
prices or rates, actors involved in hotel business business activities, number of facilities and infrastructure as well as hotel and hotel facilities etc. This data is secondary data that will complete the primary data that has been obtained through questionnaires. This secondary data is important to know the extent of the development of the sharia-based hotel industry in Jember district.

\section{Data Sources:}

a. Primary Data is data obtained directly from the first party that can be obtained through direct interviews with hotel management or by giving questionnaires to consumers or respondents who use the hotel accommodation services. This primary data is then used to determine the perceptions of tourists about the management of shariabased hotels: Services and hotel work procedures.

b. Secondary data is data obtained from certain parties in the form of formal records and is not the first source, for example data obtained from related institutions such as the Jember branch of PHRI, the Jember Tourism Office and so on are adjusted to the research needs. This data is complementary to the primary data as well as comparative data to answer the research problem, which is to determine the perceptions of tourists towards the management of sharia-based hotels: Services and hotel work procedures.

\section{Research Stage}

a. Preparation phase

At the preparation stage is a stage where researchers need to prepare themselves for everything related to the basic material of the research itself. The techniques used in this preparation stage are:

1). Literature review

Researchers conduct literature studies in order to gain deeper and more comprehensive knowledge and insights by gathering various theories and concepts related to human behavior in organizations, perceptions and characteristics of tourists, motivation of tourists staying in hotels and so on in accordance with research needs. Literature study is intended to increase the author's reference to the research problem.

2). Determination of Research Locations

This research was conducted in hotels in Jember, especially hotels that pledged to be based on sharia, namely a case study at the Seven Dream hotel.

3). Preliminary Observation

Preliminary observations are intended to determine the subject and object of research. The subjects are consumers of hotel accommodation service users with shariabased management. The object of this research is a case study in a seven dream hotel.

4). Population and sample collection

Scientific research is always confronted with the problem of data sources called populations and samples. Population is a generalization area consisting of objects / subjects that have certain quantities and characteristics determined by researchers to study and then draw conclusions, so the population is not only people, but also other natural objects. Population is also not just the amount that exists on the object / subject studied, but includes all the characteristics / properties possessed by the object or subject 
(Sugiyono, 2001). The sampling technique is done by using random sampling techniques is a way of taking elements from the population such that each element gets the same opportunity to be selected as a sample member. (Marzuki, 2002). So based on this understanding, this study uses 60 respondents because there is no clear limit on how many samples should be taken in a study. The technique is taken accidentally to the consumers of hotel accommodation service users. Where the authors provide a list of questions and accompany while interviewing so that hotel accommodation service users are free to answer the list of questions that researchers provide. This researchers do until the next consumer until fulfilled in accordance with the required sample.

b. Data Collection Stage

Data collection phase aims to obtain the data needed in research, data collection in this study uses several techniques, including:

1) Direct Interview

Interviews were conducted to obtain in-depth and accurate research data. Interviews were conducted with competent parties in the hotel world, namely: general manager of the Seven Dream Hotel, PHRI, Jember Regency Tourism Office as well as other parties other competent to study and collect their perceptions of research problems.

2) Questionnaire

Data collection by means of a questionnaire was carried out by providing a number of questionnaires to respondents in order to obtain data on the Supervision of Restaurants' As a Sharia Based Hotel Implementation in Jember City Data from these respondents will then be analyzed to answer the research problem. The questionnaire model distributed was closed and open because in addition to the answers already determined in advance, but respondents were also given the opportunity to give answers openly. (Singarimbun, 1987)

c. Data Analysis Stages

Data analysis techniques used to study this is by collecting data derived from interviews / interviews, observations, literature studies. Then the data is classified and identified based on patterns, themes and sub-themes. Furthermore, the data is grouped and categorized, so that the relationship between the things that causes it and the end result in these things can be interpreted then it is interpreted with relevant theories so that it can be analyzed so that it becomes the desired result to answer the problems. the problem.

In Islamic teachings, all types of food and drinks are basically halal, except for only a few that are forbidden. That is forbidden becomes lawful when in an emergency. Conversely, halal can be haram if consumed beyond the limit.

Understanding halal and haram is actually not only related to the problem of food and drinks, but also concerning the action. So there are actions that are permitted, there are also actions that are forbidden.

The definition of halal food and drink includes:

a. Substance is Halal

b. Halal how to process it

c. Halal how to get it, and

d. Non-halal drinks 
The steps undertaken by the authors in this study as stated by Miles and Huberman suggest that the three steps undertaken by the study are data reduction, data display and conclusion drawing / verification.

1. Data reduction

is summarizing, selecting the main data and focusing the main data based on the theme with the aim to provide a detailed description of an event so that it makes it easier for research to find and collect and group data in the data analysis process

2. Data display (data presentation)

In this stage the data will be presented in tabular form, a brief description, a chart. Miles and Huberman present the data in this study in the form of narrative text

3. Conclusion drawing / verification (conclusion and verification)

According to Miles and Huberman, this stage is the concluding and verification of temporary data, and will change if no new evidence is found that is strong and supportive in the next stage of data collection. But if the conclusions raised at an early stage are supported by valid and consistent evidence, then the conclusions put forward are credible conclusions. In this stage the conclusion can be in the form of a description or description and is supported by other theories or researchers

In classifying answers from respondents in order to smoothly reduce, present data and classify data, the researcher uses the following steps as performed by Veithzal Rivai and Ahmad Fawzi Mohd. Basri (2005: 467)

\section{Descriptive Analysis}

Descriptive analysis is used to answer the problem of how the Supervision of halal restaurants as the implementation of sharia hotels: Supervision of halal restaurants and halal supervision procedures as implementation of sharia-based hotels.

e. Conclusion Withdrawal Phase

At the final stage of the study it is necessary to draw conclusions from the results studied, namely drawing conclusions based on data and formulations that have been analyzed to solve the problems raised.

\section{DISCUSSION}

\section{General description of restaurant halal control as implementation of Sharia-based hotels}

Seven Dream Syariah Hotel is a hotel in the category of Hotels with an address on Jl. Riau No. 2, Jember - Indonesia. The room rates offered are quite varied according to the room size and quality of a 2-star hotel, Seven Dream Syariah Hotel consists of thirty rooms with Jasmine type (twin beds), Jasmine (double beds), Orchid (twin beds).

General description of the Seven Dream Syariah Hotel restaurant is a business providing food and beverage services equipped with equipment and supplies for the process of making, storing and serving in a fixed place that is not moved with the aim of gaining profit and / or profit. 


\section{Hotels Based on Sharia Concepts}

Hotels that are in accordance with sharia principles are hotels that provide lodging, dining and drinking services and other services to the public, are managed commercially, and meet the conditions set by the government and are not in conflict with Islamic principles. All components of the hotel operational technical requirements criteria, from small things such as what information must be available at the concierge, istinja equipment that must be available in public toilets, food and beverage serving to reception policies and procedures at the fornt office must ensure all Sharia provisions. In summary, it can be concluded that the business guidelines in sharia, viz

Not producing, trading, providing, renting out a product or service that all or part of the service or product is prohibited or not recommended in sharia. Such as foods containing elements of pork, alcoholic drinks or intoxicants, gambling, adultery, pornography, porno-action and others - others

Transactions must be based on a real service or product, it really exists. There is no tyranny, kemudharatan, mungkar, damage, disobedience, error and involvement, both directly and indirectly in an action or thing that is prohibited or not recommended by sharia. There is no element of fraud, lies, obscurity (gharar), excessive risk, corruption, manipulation and ribawi or get an outcome without willing to participate in business or bear the risk.

\section{Overall commitment to the agreement made.}

From the business guidelines in sharia mentioned above, the hotel operations will be aligned. After knowing the side of the hotel operations then made the standards or criteria for Islamic hotels, as follows:

\section{a. Amenities}

All facilities both basic facilities that must be owned by the hotel or additional facilities are facilities that will provide positive benefits for guests. As for facilities that can have an impact on damage, munkar, division, arouse lust, exploitation of women and others of the same type are eliminated. The entertainment facilities for procurement refer to the Sharia method. Adjustment of hotel products and facilities in accordance with sharia by removing and closing products and facilities that are not sharia compliant (such as night).

clubs, discos, bars with alcoholic drinks) and replaced with similar forms in accordance with sharia. Neutral facilities (such as swimming pools, fitness centers, massages) are only regulated so that their use does not violate sharia. The use of the facilities provided is also adjusted to the purpose of holding them so that there is no misuse of the facilities. deviations in the use of facilities.

b. Guest Check-in

Guests who check-in, especially for couples of the opposite sex, do a guest selection (reception policy). spouse is husband and wife or not to prevent the hotel used for adultery.

c. Marketing 
Open to anyone, personal or group, formal or informal with various ethnic, religious, racial and group groups. As for the group or group its activities are not prohibited by the state and do not constitute advocates of damage, munkar and hostility as well as other similar acts.

\section{d. Food and Drink}

Food and beverages provided are food and beverages that are not prohibited by sharia (halal). In making food and drinks both the ingredients and the production process must be guaranteed halal (not mixed with ingredients that are prohibited by sharia). The restaurant is open at any time as well as in the month of Ramadan for people who travel long distances (safar), women who are unable to fast and people who have old Shari'i by not reducing respect for those who fast.

\section{e. Decoration and Ornamentation.}

Decoration and ornaments are adjusted to the values of beauty in Islam and do not conflict with sharia. Sculpture ornamentation is eliminated as well as paintings of living things avoided. The hotel decoration also does not have to be in Arabic writing.

f. Operational, operational areas include:

1. Policy

Company policies in the form of management policies and regulations must be in accordance with sharia values. Likewise, the exit policy either in the form of cooperation or investment and business development is carried out with partners whose business activities are not prohibited from sharia and for businesses that are not prohibited from sharia.

\section{Service}

The services provided are services provided in accordance with Islamic methods that meet aspects of hospitality, friendliness, honesty, trustworthy, like to help and say the word sorry and thank you. Services must also be carried out within the limits permitted by the sharia, ie not lead to khalwat (mixing between men and women who are not in accordance with sharia principles).

\section{g. HR Management}

Acceptance and recruitment do not differentiate between ethnicity, religion, as long as they meet predetermined qualification standards, are moral and are able to comply with applicable company rules. Companies must be honest with employees in giving up their rights and employees must be honest and trustworthy in carrying out

their obligations. The company is needed by employees according to the dress code in Islam. As for non-Muslim employees, it is recommended to dress according to Islamic rules but not be forced and if they refuse they still have to fulfill eastern norms in dressing. Human resource management also refers to improving quality which includes three things, namely ethics, knowledge and skills (skills).

\section{h. Finance}

Financial management is adjusted to the Islamic sharia financial management system (Sharia Accounting). Partnerships with financial institutions (banks) and insurance are carried out with banks and Islamic insurance. Then if the company has sufficient profits to calculate the zakat, the company is obliged to issue zakat and not justify the practice of mark-up. 


\section{i. Structure}

The existence of an institution that oversees the operation of sharia hotels and which will provide direction and answer problems that arise in day-to-day hotel management relating to the implementation of sharia hotel operations. This institution is the Sharia Supervisory Board. People who sit in it are people with sharia education background who have knowledge of the legal principles in Islamic sharia. The appointment of the Sharia Supervisory Board is carried out with the approval of the National Sharia CouncilIndonesian Ulema Council.

j. Worship facilities

The hotel must be equipped with a mosque or mosque that is comfortable and representative. Prayers must be echoed at every time Fardhu prayers, mounted speakers to continue the call to prayer on every corner or floor of the hotel. Each hotel room is facilitated with worship equipment such as mukena and sarong, prayer rugs, Al-Qur'an, clearly determined direction of Qibla, and Islamic nuances.

$\mathrm{k}$. There needs to be a special section in the hotel that deals with the spiritual intelligence problems of its employees. Then it is necessary to hold routine study of employees, and also Islamic training to increase the appreciation of the beauty of sharia.

\section{Islamic views about Halal}

The words "halal" and "haram" are Qur'anic terms and they are used in various places with different concepts, and some are related to food and drink. Both of these words are also used in the Hadith of the Prophet. Halal in language, according to some opinions, comes from the root word $\lambda\rfloor$ which means (ö (meaning something that is permitted), according to Shari'a. Al-Jurjani writes, the word "halal" comes from the word

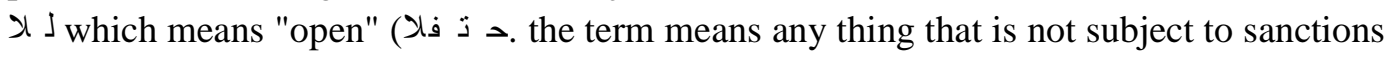
for its use or something which the Shari'ah is free to do. "2 According to Abû Ja'far al-

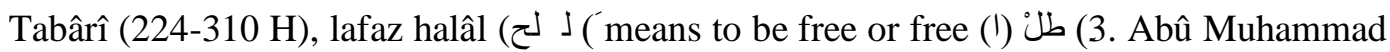
al-Husayn ibn Mas'ûd al-Baghawî (436-510H) of the Syaf'i school, believes the word "hal" means something that is permissible by the Shari'a because it is good.4 Muhammad ibn 'Ali al-Syawkânî ( 1759-1834 H) argues, is declared as halal because of the breaking of the knot or the prohibiting ties.5 In line with the opinion of al-Syawkânî (1759-1834 $\mathrm{H}$ ), among contemporary scholars, such as Yusuf al-Qaradhawî, defines halal as something with which a dangerous knot is broken down, and Allah allows it to be done.6 While 'Abd al-Rahman ibn Nāshir ibn alSa'dî' when defining the word "halal" sheds light on how to obtain it, not by way of ghashab, stealing, and not as the results of muamalah are unclean or in the form of haram.7 From some of the explanations above, it can be drawn halal conclusion is something that is permitted by the Shari'ah to (i) be done, (ii) used, or (iii) sought, because it has broken down the rope or bond prevent it or the elements that endanger it with attention to how to obtain it, not with muamalah results that are prohibited.

\section{Islamic view of food}

Islamic teachings cover all aspects of life, including the problem of eating. Therefore, for Muslims, food aside is related to meeting physical needs, it is also related 
to spirituality, faith and worship as well as self-identity, even with behavior.Allah tells people to eat anything in this world that He created, along the limits of lawful and good (tayibah). In addition to the verses above, there are many more verses in the Qur'an that contain instructions or instructions that humans be careful in choosing food, can separate what is halal (allowed) and what is haram (not permitted), how to obtain food and food is both in terms of physical and spiritual health, as in the verses: QS Al Baqarah (2): 172, QS An Nahl (16): 114, QS Al Múminun.(23): 51, Surah Al Araaf (7): 31, Surah Al Anam (6): 145, Surah Al Maidah (5): 3, Surah Al Anam (6): 121 Surah Al Baqarah (2): 173, QS An Nahl (16): 115.And ordered by humans to always pay attention to food, like the word of God "Then humans should pay attention to food" (Surah Abasa (80): 24). "Caliph Fil Ardhi". Rasulullah SAW once said in a hadith: "A servant of Allah will not move two feet even on the Day of Resurrection, until he is able to answer four things: how old is spent, knowledge how to practice, treasure how to be donated and how the body is used or wasted" (HR.Tirmidzi ).

\section{Islamic view of halal and haram food}

In Islamic teachings, all types of food and drinks are basically halal, except for only a few that are forbidden. That is forbidden becomes lawful when in an emergency. Conversely, halal can be haram if consumed beyond the limit. Understanding halal and haram is actually not only related to the problem of food and drinks, but also concerning the action. So there are actions that are permitted, there are also actions that are forbidden.

The definition of halal food and drink includes:

a. Substance is Halal

b. Halal how to process it

c. Halal how to get it, and

d. Drinks are not my thing

\section{Foods that are halal in substance}

Allah is most gracious, most gracious. Too much, even almost all types of food are halal and can be consumed. Conversely too few types of prohibited foods that should not be consumed. The wisdom of the ban is clearly Allah who knows. The goodness of the existence of the prohibition is clearly for the benefit and goodness of humanity itself. Among other things, as a testament to spiritual obedience through food and drink and so people know / want to be grateful.

Carriages, blood and pigs are strictly forbidden by Allah, according to the above verse. Furthermore, all animals that die do not go through the process of slaughtering haraam, equated with the carcass. Including animals that die in transportation even if only briefly, may not be slaughtered and consumed by humans.

\section{Halal food according to the process}

Halal food but if it is processed in a non-halal way, it becomes unclean. Process it unlawfully when it's done: 
Animal slaughter that is not done by a Muslim, by not mentioning in the name of Allah and using a sharp knife. Slaughter of animals that are clearly designated or offered to idols (offerings). Because the blood is forbidden, then in slaughter, the blood of the slaughtered animal must come out completely, and the blood vessels and blood vessels must be broken and must be done politely, using a sharp knife. Halal animal flesh is contaminated by illicit substances or is not halal. The definition of tainted here can be through mixing with non-halal materials, in the form of raw materials, herbs or other supporting materials. It could also be because there is no separate place and the tools used to process the material are not

lawful. The fish both living in fresh water and those that live in sea water are all halal, even without slaughtering, including all types of animals that live in water. In addition to the above, there are several types of animals that are forbidden by the opinions of scholars, but basically still invite differences of opinion.

\section{Halal how to get it}

A devout Muslim is very concerned about the food he consumes. Islam provides guidance so that Muslims only eat and drink halal and thoyyib, meaning that food is spiritually healthy and hygienic.

\section{Non-halal drinks}

All types of intoxicating drinks are haram. This includes drinks that are contaminated with intoxicants or non-halal ingredients. The habit of getting drunk by drinking liquor apparently has been around for a long time and is a habit by almost all nations of the world. During the time of the prophet Muhammad SAW, the Arab community also had this custom. The Prophet gradually eradicated this bad habit. First, forbid people from praying while still drunk (QS 4:34). Next states that the khamar or liquor is a sin or an ugliness greater than the benefits or goodness (QS 2: 219). Finally, the new prohibition explicitly states that liquor is a heinous act, as an act of the devil, because it is really shunned (QS 5:90 
Proceeding ICOGISS 2019

Page 91-104. ISBN: 978-602-6 988-75-1

Web Jurnal Online: jurnal.unmuhjember.ac.id

By: Syah Riza Octavy Sandy

Supervision of Halal Food as Implementation of Sharia-Based Hotels in Jember City

\section{REFERENCE}

Endar, Sugiarto dan Sri Sulartiningrum. Pengantar Industri Akomodasi dan Restoran. Jakarta : Gramedia Pustaka Utama, 1996

Fatwa Dewan Pengawas Syariah PT Sofyan Hotels Tbk No.01/FTW- DPS/SH/V/02 tentangBisnis Hotel, tanggal 23 Mei 2002/10 RabiulAwal 1423 H

Qaradhawi, Yusuf. Halal dan Haram : Jabal,

Fida, Yazid Abu. Ensiklopedi Halal Haram Makanan : Pustaka Arafah, 2004 Shalih bin Fauzan bin Abdillah al-Fauzan. Fiqih Makanan (Tentang MakananHalal \& Haram): Griya Ilmu, 2005

https://www.halalmuibali.or.id/pengertian-halal-dan-haram-menurutajaran-

islam/Pengertian Halal dan Haram MenurutAjaran Islam (I), di aksestanggal 20 Mei2019

Napitasari, Amarinda. AnalisisMinatBeliKonsumen Pada RestoranBersertifikat Halal Mui Di Daerah Istimewa Yogyakarta Tahun 2018, Sarjana Thesis, 2018

Ali, Muchtar. Konsep Makanan Halal Dalam Tinjauan Syariah Dan Tanggung Jawab Produk Atas Produsen Industri Halal, Artikel. Kementrian Agama Republik Indonesia, 2016

Hadi, Rara Angelina Puspita.Analisis Titik Kontrol Kehalalan Restoran Sebagai Penunjang Implementasi Hotel Syariah (Studi Kasus di Hotel Fariz Syariah Kota Malang). Sarjana thesis, Universitas Brawijaya. (2017)

Kementerian Agama RI. Alquran dan Terjemahnya. Cet. I; Bandung: Syamil Qur'an, 2012

Kotler, Philip, John Bowen, dan James Maken. 2003. Marketing for Hospitality and Tourism, $3^{\text {rd }}$. ed., Intenational Edition, Upper Saddle River : Practice- Hall.

Sabri, Fahruddin Ali. Perkembangan Hotel Syariah Di Indonesia : Mengonsep Pariwisata Islami, Jurnal KARSA, Vol. XVIII No. 2 Oktober 2010

Singarimbun Masri dkk, 1989, Metode Penelitian Survey. Gramedia Jakarta Sofyan, Riyanto. Bisnis Syariah, Mengapa Tidak? Pengalaman Penerapan Pada

Bisnis Hotel, Jakarta : PT. Gramedia Pustaka Utama, 2007 